\title{
IMPLEMENTASI PERATURAN PEMERINTAH NOMOR 18 TAHUN 2016 TENTANG PERANGKAT DAERAH TERHADAP EFEKTIVITAS KINERJA PEGAWAI SEKRETARIAT DAERAH DEWAN PERWAKILAN RAKYAT DAERAH (DPRD) DI KABUPATEN NGAWI
}

\author{
Suprianto \\ E-mail: bresuprianto@gmail.com \\ Mahasiswa Prgram Magister Ilmu Hukum \\ Universitas Sebelas Maret Surakarta \\ Agus Riwanto \\ E-mail: agusriewanto@yahoo.com \\ Sunny Ummul Firdaus \\ E-mail: firdaussunny@yahoo.com \\ Dosen Fakultas Hukum Universitas Sebelas Maret Surakarta
}

\begin{abstract}
This article aims to analyze the implementation of government regulation No. 18 of 2016 on the regional apparatus against the effectiveness of the performance of employees in the local secretariat of the regional parliament (DPRD) in the district Ngawi. The research is research law that is evaluative with the empirical approach and sociological approach.The theory used for the analysis in this research is the theory of Lawrence M. Friedman with its three legal structures, from the analysis it is known that the performance of the employees in the local secretariat environment The ngawi district representative board is quite good but needs many new innovations and improvements in some aspects, in both the legal aspect in the legal structure theory of friedman found that only in the aspect of the element of law culture which is not appropriate to the implementation of Government Regulation No. 18 of 2016 on the Regional Devices in Ngawi District is less able to improve the effectiveness of the performance of the Secretariat staff of Ngawi Regency DPRD. The competence of employees who moved from the merger of other agencies and agencies in accordance with Government Regulation No. 18 of 2016 is not in accordance with the needs of the Secretariat of Ngawi Regency DPRD, while in the other two aspects are appropriate.
\end{abstract}

Keywords: implementation of government regulation; effectiveness; law culture.

\begin{abstract}
Abstrak
Artikel ini bertujuan untuk menganalisis implementasi peraturan pemerintah Nomor 18 tahun 2016 tentang perangkat daerah terhadap efektivitas kinerja pegawai di lingkungan sekretariat daerah dewan perwakilan rakyat daerah (DPRD) di kabupaten ngawi. Berdasarkan bentuknya penelitian ini termasuk dalam evaluatif, yaitu "suatu bentuk penelitian yang dimaksudkan untuk menilai suatu program kerja. Teori yang dipakai untuk analisis dalam penelitian ini adalah teori dari Lawrence M. Friedman dengan tiga struktur hukumnya, dari analisis diketahui bahwa kinerja para pegawai di lingkungan sekretariat daerah Dewan perwakilan daerah kabupaten ngawi cukup baik namun perlu banyak inovasi baru dan peningkatan dibeberapa aspek, di kedua aspek hukum dalam teori struktur hukum dari friedman didapatkan bahwa hanya dalam aspek dari unsur
\end{abstract}


kultur hukum saja yang tidak sesuai implementasi Peraturan Pemerintah Nomor 18 Tahun 2016 tentang Perangkat Daerah di Kabupaten Ngawi kurang mampu meningkatkan efektivitas kinerja pegawai Sekretariat DPRD Kabupaten Ngawi. Kompetensi pegawai yang pindah dari adanya penggabungan Dinas dan Badan lain sesuai dengan Peraturan Pemerintah Nomor 18 Tahun 2016 tidak sesuai dengan kebutuhan Sekretariat DPRD Kabupaten Ngawi, sementara dalam kedua aspek lainnya sesuai.

Kata kunci: implementasi peraturan pemerintah; efektivitas; kultur hukum.

\section{A. Pendahuluan}

Revolusi mental yang menjadi sarana percepatan reformasi birokrasi memaksa aparatur negara untuk bertransformasi diri menjadi aparatur yang lebih kompeten dan profesional. Permintaan dari internal instansi dan tuntutan dari masyarakat mendorong PNS untuk bergulat dengan perubahan serta peningkatan kinerja secara berkelanjutan guna menyukseskan reformasi birokrasi. Peningkatan kinerja yang terus dilakukan guna mencapai tingkatan good goverment masih meninggalkan beberapa permasalahan yang harus segera diselesaikan.

Salah satu upaya untuk mengatasi permasalahan tentang peningkatan kinerja maka organisasi perlu menyusun struktur organisasi yang benar-benar mampu menunjang pencapaian tujuan oprganisasi. Peraturan Pemerintah Nomor 18 Tahun 2016 tentang Perangkat Daerah telah berpengaruh cukup besar bagi perombakan susunan satuan kerja perangkat daerah dalam lingkup penyelenggaraan pemerintahan daerah, sehingga perlu penyelerasan RPJMD bagi daerah itu sendiri yang pada akhirnya berpengaruh pula pada penyelerasan Renstra satuan kerja perangkat daerah. Peraturan Pemerintah Nomor 18 Tahun 2016 ini disusun untuk melaksanakan ketentuan Pasal 232 ayat (1) Undang-Undang Nomor 23 Tahun 2014 tentang Pemerintahan Daerah yaitu mengatur tentang kedudukan, susunan organisasi, tugas dan fungsi, tata kerja, eselon, beban kerja, nomenklatur unit kerja, serta pembinaan dan pengendalian.

Sebagaimana umumnya bahwa tujuan setiap organisasi, baik organisasi publik maupun swasta akan dapat tercapai dengan baik apabila pegawai dapat menjalankan tugas-tugasnya dengan efisien. Oleh karena itu untuk meningkatkan kemampuan kerja (produktivitas) para pegawai, organisasi harus menjalankan usaha-usaha pengembangan pegawai. Jadi pengembangan pegawai adalah untuk memperbaiki efektivitas kerja pegawai dalam mencapai hasil-hasil kerja yang ditetapkan. Perbaikan efektivitas kerja pegawai dalam mencapai hasilhasil kerja yang ditetapkan. Perbaikan efektivitas kerja dapat dilakukan dengan memperbaiki pengetahuan, ketrampilan maupun sikap pegawai itu sendiri terhadap tugas-tugasnya (Heidjrachman Ranupandojo dan Suad Husnan, 2009: 67-71).

Keterampilan pegawai perlu dimanfaatkan secara optimal oleh organisasi. Organisasi harus dapat mendayagunakan seluruh sumber daya manusia yang ada di dalamnya guna mencapai tujuan yang telah ditetapkan. Dari pada itu baru diuji sebenarnya untuk manajemen yang baik adalah kemampuan organisasi dan memanfaatkan sumberdaya yang tersedia dalam tugas untuk mencapai dan memiliki sesuatu tingkat efektivitas (Richard M. Steers, 2005: 1). Hal ini diperkuat pendapat Kamarudin yang mengatakan bahwa efektivitas kerja adalah suatu keadaan yang menunjukan tingkat keberhasilan di atas kegiatan manajemen dalam 
mencapai tujuan yang telah ditetapkan lebih dahulu (Ahmad Kamarudin,2008: 2). Organisasi akan dapat mencapai tujuan dan sasaran jika efektivitas kerja pegawai dapat ditingkatkan.

Berdasarkan pendapat para ahli di atas pada intinya efektivitas adalah ketepatan pegawai dalam menyelesaikan tugas sesuai dengan yang telah ditetapkan oleh organisasi. Sehubungan dengan itu, Muhammad As'ad mengatakan bahwa pelaksanaan pekerjaan dikatakan efektivitas apabila mampu merealisasikan sasaran-sasaran pekerjaan. Wujud dari efektivitas adalah tumbuhnya kemahiran kerja dan kuantitatif secara kualitas hasil kerja (Muhammad As'ad, 2007: 112).

Peraturan Pemerintah Nomor 18 Tahun 2016 tentang Perangkat Daerah merupakan kebijakan yang diambil untuk memnyemperunakan Peraturan Pemerintah Nomor 41 Tahun 2007 tentang Perangkat Daerah. Peraturan ini pada dasarnya dimaksudkan untuk memberikan arah dan pedoman yang jelas kepada daerah dalam menata organisasi yang efisien, efektif dan rasional sesuai dengan kebutuhan dan kemampuan daerah masing-masing serta adanya koordinasi, integrasi, sinkronisasi dan simplikasi serta komunikasi kelembagaan antara pusat dan daerah. Besaran organisasi perangkat daerah sekurang-kurangnya mempertimbangkan faktor keuangan, kebutuhan daerah, cakupan tugas yang meliputi sasaran tugas yang harus diwujudkan, jenis dan banyaknya tugas, luas wilayah kerja dan kondisi geografis, jumlah dan kepadatan penduduk, potensi daerah yang bertalian dengan urusan yang akan ditangani, sarana dan prasarana penunjang tugas. Oleh karena itu kebutuhan akan organisasi perangkat daerah bagi masing-masing daerah di Indonesia tidak senantiasa sama atau seragam (www. ali-habiu.blogspot.com, diakses pada tanggal 16 Juli 2017).

Keharusan pemerintah daerah untuk melakukan restrukturisasi terhadap birokrasi haruslah sejalan dengan perkembangan paradigma penyelenggaraan pemerintahan yang harus mampu mewujudkan prinsip-prinsip Good Governance khususnya di tingkat lokal. Sehingga diharapkan melalui restrukturisasi birokrasi, pemerintah daerah dapat mampu menciptakan pemberdayaan masyarakat.

Penentuan jumlah perangkat daerah sesuai dengan jumlah nilai yang ditetapkan berdasarkan perhitungan dari variabel, dan masing-masing pemerintah daerah tidak mutlak membentuk sejumlah perangkat daerah yang telah ditentukan sesuai dengan variabel tersebut. Urusan pemerintahan yang perlu ditangani terdiri dari urusan wajib dan urusan pilihan. Masing-masing urusan pada prinsipnya tidak mutlak dibentuk dalam lembaga tersendiri, namun sebaliknya masing-masing urusan dapat dikembangkan atau dibentuk lebih dari satu lembaga perangkat daerah sesuai dengan prinsip-prinsip organisasi, kebutuhan dan kemampuan daerah masing-masing.

Dengan dilakukannya Restrukturisasi Birokrasi diharapkan bermuara pada sebuah Birokrasi Pemerintah Daerah yang tampil dengan penampilan yang fit dan prima. Performa yang diharapkan tersebut seharusnya tidak lagi seperti yang terjadi pada masa lalu, yaitu sebuah birokrasi pemerintah daerah yang gemuk dan lamban sehingga banyak memerlukan resources, namun harus eksis dan ramping serta kaya akan fungsi. Apabila birokrasi pemerintah daerah bisa tampil dengan performa "lean and mean" maka kehendak untuk memberdayakan rakyat mudah-mudahan dapat diwujudkan. Karena sumber daya yang selama ini dipakai untuk birokrasi bisa digunakan untuk memberdayakan masyarakat. Dengan berdayanya masyarakat maka akan ada keseimbangan peran dari semua unsur 
penopang Good Governance (kurnia-one75.blogspot.com/2008/04/restrukturisasi-birokrasi. html, diakses 17 Juli 2017)

Untuk menciptakan kondisi yang diharapkan itu, maka birokrasi tersebut harus mampu merubah dirinya menjadi sebuah organisasi yang dapat meningkatkan kompetensi administrasi, transparan dan efisien. Kompetensi administrasi dari birokrasi pemerintah daerah akan memungkinkan organisasi tersebut memiliki kompetensi institusi dan personil. Untuk itu, maka dalam konteks restrukturisasi birokrasi yang dilaksanakan oleh pemerintah daerah, organisasi birokrasi harus memiliki kedua kompetensi itu. Kompetensi kelembagaan mengandung makna bahwa organisasi yang dibentuk benar-benar memiliki kewenangan dan kemampuan untuk melaksanakan tugas pokok dan fungsinya secara efektif dan efisien. Kompetensi kelembagaan dimaksudkan untuk menghindari adanya duplikasi pelaksanaan tugas (overlapping) karena dengan adanya kompetensi lembaga maka setiap lembaga akan memiliki karakteristik yang berbeda dengan lembaga lainnya dalam menjalankan aktivitas dan mencapai tujuan organisasi.

Peraturan Pemerintah Nomor 18 Tahun 2016 tentang Perangkat Daerah telah memberikan pedoman dalam arah dan pedoman agar kinerja organisasi perangkat daerah lebih efektif dan efisien. Namun implementasinya di lingkungan Sekretariat DPRD Kabupaten Ngawi, masih ditemui kegiatan pegawai yang menunjukkan tingkat efektivitas kerja yang rendah. Hal ini nampak dari waktu yang dibutuhkan pegawai dalam menyelesaikan tugas masih kurang cepat, sehingga administrasi di sekretariat DPRD menjadi terhambat. Masih ditemui pegawai yang masuk kerja tidak tepat waktu, dan datang di kantor tidak segera melakukan aktivitas pekerjaan yang produktif malah seenaknya ngobrol dan bercanda dengan rekan kerja.

Hasil pengamatan awal juga menemukan kondisi adanya pegawai nampak sibuk dengan laptop di mejanya, namun ketika didekati ternyata malah sedang asyik membuka akun jejaring sosial. Walau tidak semua pegawai melakukan kegiatan yang tidak efektif seperti hasil temuan awal di atas namun hal ini menggambarkan potret kinerja pegawai yang kurang efektif. Pimpinan sudah memberi teguran terhadap pegawai yang kinerjanya kurang baik, namun tidak ada sanksi yang tegas dan membuat jera para pegawai negeri sipil ini membuat mereka kembali melakukan kesalahan atau tindakan yang kurang menunjukkan kinerja yang baik bagi organisasi. Jika hal ini terus berlanjut maka tujuan organisasi akan sulit untuk tercapai.

Sturktur organisasi yang baik tentu polanya mengerucut seperti piramida. Pegawai di sekretariat DPRD Kabupaten Ngawi banyak yang memenuhi persyaratan untuk menjadi posisi yang lebih tinggi daripada posisinya sekarang karena telah mengikuti diklat pimpinan. Dengan adanya Peraturan Pemerintah Nomor 18 Tahun 2016, struktur organisasi dituntut untuk lebih ramping agar kinerja organisasi menjadi lebih efisien. Hal ini tentu berpengaruh terhadap efektivitas pegawai karena hasil diklatnya tidak dapat diterapkan karena terbentur kewenangan dalam struktur organisasi. Untuk itu perlu diketahui dampaknya secara langsung terhadap pelaksanaan kerja pegawai pda Sekretariat DPRD di Kabupaten Ngawi.

Berdasarkan latar belakang masalah tersebut di atas, maka yang akan dibahas dalam penulisan ini adalah Apakah implementasi Peraturan Pemerintah Nomor 18 Tahun 2016 mampu meningkatkan efektivitas kinerja pegawai sekretariat DPRD di Kabupaten Ngawi? 


\section{B. Metode Penelitian}

Berdasarkan bentuknya penelitian ini termasuk dalam evaluatif, yaitu "suatu bentuk penelitian yang dimaksudkan untuk menilai suatu program kerja" (Djoko Purwito, 2009: 9). Penelitian ini akan mengevaluasi implementasi Peraturan Pemerintah Nomor 18 Tahun 2016 tentang Perangkat Daerah serta pengaruhnya terhadap efektivitas kinerja pegawai. Dalam pelaksanaan evaluasi pada penelitian ini digunakan jenis penelitian kualitatif, yaitu "suatu bentuk penelitian yang model analisisnya tidak menggunakan analisis statistik atau non statistik".

Penelitian ini dilaksanakan pada Sekretariat Dewan Perwakilan Rakyat Daerah Tingkat II Kabupaten Ngawi yang beralamatkan pada Jalan Jaksa Agung Suprapto Nomor 1, Kelurahan Ketanggi, Kecamatan Ngawi, Kabupaten Ngawi Telp. 0351747661.

Data yang digunakan dalam penelitian ini adalah data primer dan data sekunder.

1. Data Primer

Data primer dalam penelitian ini adalah data deskripsi lokasi penelitian yaitu tentang Struktur Organisasi sebelum dan sesudah implementasi Peraturan Pemerintah Nomor 18 Tahun 2016, Tugas Pokok dan Fungsi, Visi dan Misi serta Tujuan Sekretariat Dewan Perwakilan Rakyat Daerah Kabupaten Ngawi.

2. Data Sekunder

Data sekunder umumnya berupa bukti, catatan atau laporan historis yang telah tersusun dalam arsip (data dokumenter) yang dipublikasikan dan yang tidak dipublikasikan. Data sekunder dalam penelitian ini merupakan data tentang hasil wawancara dengan:

a. Sekretaris DPRD Kabupaten Ngawi

b. Kepala Bagian Umum Sekretariat DPRD Kabupaten Ngawi

c. Kepala Sub Bagian Tata Usaha Sekretariat DPRD Kabupaten Ngawi

Analisis data dalam penelitian ini dilakukan secara deskriptif kualitatif, dan interpretatif.

\section{Hasil Penelitian dan Pembahasan}

Pembahasan masalah yang menjadi fokus penelitian ini menggunakan teori bekerjanya hukum Lawrence Meir Friedmen sebagaimana dikutip Esmi Warasih bahwa untuk penerapan sistem hukum harus secara lengkap berdasar teori bekerjanya hukum sebagai suatu proses, hal ini ada tiga komponen diantaranya adalah (Esmi Warassih, 2005: 30)

1. Struktur Hukum (Legal Structure), yang mencakup institusi-institusi penegak hukum termasuk penegak hukumnya;

2. Substansi Hukum (Legal Substance), mencakup aturan-aturan hukum, baik yang tertulis maupun tidak tertulis termasuk pola perilaku nyata manusia yang termasuk dalam suatu sistem, bisa juga berupa produk yang dihasilkan oleh orang yang berada pada suatu sistem hukum, mencakup keputusan yang mereka ambil;

3. Kultur Hukum ( Legal Culture), mencakup sikap manusia terhadap hukum dan sistem hukum - kepercayaan, nilai, pemikiran serta konstruksi ideal. 


\section{ad 1. Unsur Struktur Hukum (Legal Structure)}

Implementasi Peraturan Pemerintah Nomor 18 Tahun 2016 ditinjau dari unsur struktur hukum tentu tidak lepas dari para pemangku jabatan yang menjalankan peraturan pemerintah tersebut. Penanggungjawab utama efektivitas pelaksanaan kerja pegawai dalam hal ini adalah Sekretaris DPRD Kabupaten Ngawi. Selanjutnya Kepala Bagian dan Kepala Sub Bagian yang ada pada Sekretariat DPRD Kabupaten Ngawi merupakan komponen struktur hukum yang bertanggung-jawab terhadap pelaksanaan kerja pegawai.

Komponen struktur hukum sebagaimana dikemukakan di atas harus dapat memimpin, mengatur, mempengaruhi, memotivasi pegawai yang ada di bawah wewenangnya agar dapat menunjukkan kinerja yang optimal. Pegawai yang dapat bekerja secara efektif dan efisien, mempunyai komitmen kuat untuk memberi kontribusi positif bagi organisasi tentu akan membuat Sekretariat Daerah Kabupaten Ngawi dapat menjalankan fungsinya dengan baik sehingga tujuan yang telah ditetapkan dapat tercapai. Hal ini sesuai dengan pendapat Warts bahwa "untuk mencapai tujuan yang telah ditentukan organisasi dibutuhkan pegawai sebagai ujung tombak organisasi yang menunjukkan kinerja dengan disiplin yang tinggi" (Richaid W Warts, 1995: 193).

Guna memperkuat penjelasan di atas, maka dilakukan wawancara dengan Tri Pujo Handono selaku Sekretaris DPRD Kabupaten Ngawi yang menjelaskan bahwa :

"Peraturan Pemerintah Nomor 18 Tahun 2016 tentang Perangkat Daerah telah memberi arah yang jelas tentang tugas yang akan dilakukan masing-masing pegawai di Sekretariat DPRD Kabupaten Ngawi. Kami selalu berupaya agar pegawai dapat bekerja lebih disiplin, tepat waktu, meminimalisis terjadinya kesalahan kerja serta koordinasi antar bidang yang baik agar seluruh pegawai bekerja lebih efektif dan efisien".

Hasil wawancara di atas menunjukkan bahwa melalui implementasi Pemerintah Nomor 18 Tahun 2016 tentang Perangkat Daerah, maka Sekretariat DPRD Kabupaten Ngawi telah mampu bekerja lebih efektif sehingga kinerja organisasi secara keseluruhan menjadi semakin baik.

\section{ad 2. Unsur Substansi Hukum (Legal Substance)}

Peraturan Pemerintah Nomor 18 Tahun 2016 tentang Perangkat Daerah merupakan Pedoman bagi Pemerintah Daerah baik provinsi maupun Kabupaten/Kota dalam rangka penataan Kelembagaan Perangkat Daerah untuk pembentukan organisasi perangkat daerah berupa Dinas, Badan, Sekretariat serta Kecamatan. Pemerintah Nomor No. 18 Tahun 2016 ini adalah tindak lanjut dari amanat dalam Undang-Undang Nomor 23 Tahun 2014 tentang Pemerintahan Daerah serta adanya perubahan pembagian urusan pemerintahan antara Pemerintah Pusat, Pemerintah Provinsi dan Pemerintah Kabupaten dan Kota. Dalam Peraturan Perangkat Daerah ini memuat ketentuan-ketentuan dalam pembentukan satuan kerja perangkat daerah, jenis, kriteria tipelogi, hingga pada kedudukan tugas dan fungsi Perangkat Daerah.

Secara substansi hukum, implementasi Peraturan Pemerintah Nomor 18 Tahun 2016 tentang Perangkat Daerah Sekretariat DPRD Kabupaten Ngawi mendasar pada Peraturan Bupati NgawiNomor 51 Tahun 2016 tentang Kedudukan, Susunan Organisasi, Tugas Dan Fungsi Serta Tata Kerja Sekretariat Dewan Perwakilan Rakyat Daerah Tipe A. Peraturan 
Bupati Ngawi telah mengatur tugas pokok dan fungsi Sekretariat DPRD Kabupaten Ngawi serta seluruh pegawai yang ada didalamnya agar dapat mencapai kinerja yang optimal.

Pegawai Sekretariat DPRD Kabupaten Ngawi mempunyai penjelasan tentang tugas yang diemban, fungsi yang harus dijalankan serta kewenangan yang diberikan dalam menjalankan tugasnya melalui Peraturan Bupati NgawiNomor 51 Tahun 2016 tentang Kedudukan, Susunan Organisasi, Tugas Dan Fungsi Serta Tata Kerja Sekretariat Dewan Perwakilan Rakyat Daerah Tipe A. Untuk mengetahui efektivitas implementasi Peraturan Pemerintah Nomor 18 Tahun 2016 tentang Perangkat Daerah dalam meningkatkan efektivitas kerja pegawai dilakukan wawancara dengan Tri Pujo Handono selaku Sekretaris DPRD Kabupaten Ngawi sebagai berikut:

"Implementasi Peraturan Pemerintah Nomor 18 Tahun 2016 tentang Perangkat Daerah pada Sekretariat DPRD Kabupaten Ngawi membuat adanya peningkatan jumlah sub bagian disini. Awalnya tiap bagian hanya terdiri dari dua sub bagian, sekarang menjadi tiga sub bagian. Tupoksi yang diberikan juga semakin banyak sehingga target pencapaian kinerja semakin tinggi. Peningkatan sub bagian ini membuat tugas pegawai semakin fokus. Selain itu juga ada pindahan staf karena ada penggabungan dinas dan badan di Kabupaten Ngawi sesuai PP Nomor 18 tersebut. Jadi jumlah pegawai disini semakin meningkat sehingga pembagian tugas dapat dilakukan lebih mudah".

Penjelasan di atas menunjukkan bahwa Implementasi Peraturan Pemerintah Nomor 18 Tahun 2016 tentang Perangkat Daerah pada Sekretariat DPRD Kabupaten Ngawi membuat tupoksi pegawai semakin jelas, sub bagian pada organisasi semakin banyak, pembagian tugas semakin mudah serta fokus pegawai dalam menjalankan tugas juga dapat ditingkatkan. Kondisi ini membuat pelaksanaan kerja pegawai lebih efektif karena pegawai mempunyai tupoksi yang lebih detail.

Struktur organisasi bagian umum, sebelum Implementasi Peraturan Pemerintah Nomor 18 Tahun 2016 tentang Perangkat Daerah hanya terdiri dari Sub Bagian Tata Usaha dan Sub Bagian Tumah Tangga dan Perlengkapan. Setelah Peraturan Pemerintah Nomor 18 Tahun 2016 diterapkan, maka menjadi tiga sub bagian yaitu Sub Bagian Tata Usaha, Sub Bagian Tumah Tangga dan Sub Bagian Perlengkapan. Perubahan ini membuat pengaturan pegawai semakin jelas dan mudah karena adanya pemisahan wewenang dari pengembangan struktur organisasi tersebut.

Struktur organisasi Bagian Keuangan, sebelum Implementasi Peraturan Pemerintah Nomor 18 Tahun 2016 tentang Perangkat Daerah hanya terdiri dari Sub Bagian Anggaran dan Sub Bagian Perbendaharaan. Setelah Peraturan Pemerintah Nomor 18 Tahun 2016 diterapkan, maka menjadi tiga sub bagian yaitu Sub Bagian Anggaran, Sub Bagian Perbendaharaan dan Sub Bagian Pelaporan. Perubahan ini membuat kegiatan pelaporan dilakukan Sub Bagian Pelaporan yang dibentuk. Dengan demikian pegawai akan lebih fokus pada sub bagian masing-masing sehingga mampu bekerja lebih efektif.

Struktur organisasi Bagian Persidangan, sebelum Implementasi Peraturan Pemerintah Nomor 18 Tahun 2016 tentang Perangkat Daerah hanya terdiri dari Sub Bagian Rapat dan Protokol dan Sub Bagian Risalah. Setelah Peraturan Pemerintah Nomor 18 Tahun 2016 diterapkan, maka menjadi tiga sub bagian yaitu Sub Bagian Rapat, Sub Bagian Risalah dan Sub Bagian Protokol. Perubahan ini tentu diikuti dengan aturan tentang tupoksi masing- 
masing sub bagian tersebut. Pegawai akan lebih fokus terhadap tanggung-jawab yang diberikan organisasi sehingga kinerja pegawai akan lebih efektif.

Struktur organisasi Bagian Perundang-undangan, sebelum Implementasi Peraturan Pemerintah Nomor 18 Tahun 2016 tentang Perangkat Daerah hanya terdiri dari Sub Bagian Tata Perundangan dan Sub Bagian Informasi dan Dokumentasi. Setelah Peraturan Pemerintah Nomor 18 Tahun 2016 diterapkan, maka menjadi tiga sub bagian yaitu Sub Bagian Tata Perundangan, Sub Bagian Informasi dan Dokumentasi dan Sub Bagian Sub Bagian Fasilitasi Fungsi DPRD Bidang Pengawasan. Perubahan ini tentu diikuti dengan aturan tentang tupoksi masing-masing sub bagian tersebut. Pegawai akan lebih fokus terhadap tanggung-jawab yang diberikan organisasi sehingga kinerja pegawai akan lebih efektif.

Berdasarkan penjelasan di atas dapat diketahui bahwa ditinjau dari segi substansi hukum Implementasi Peraturan Pemerintah Nomor 18 Tahun 2016 tentang Perangkat Daerah mampu meningkatkan efektivitas kinerja pegawai Sekretariat DPRD Kabupaten Ngawi. Pemerintah Kabupaten Ngawi menetapkan Peraturan Bupati NgawiNomor 51 Tahun 2016 tentang Kedudukan, Susunan Organisasi, Tugas Dan Fungsi Serta Tata Kerja Sekretariat Dewan Perwakilan Rakyat Daerah Tipe Asebagai acuan pelaksanaan tugas pegawai.

\section{ad 3. Unsur Kultur Hukum ( Legal Culture)}

Peraturan Pemerintah Nomor 18 Tahun 2016 tentang Perangkat Daerah sudah jelas memberi arah tentang penyusunan organisasi perangkat daerah yang yang rasional, proporsional, efektif, dan efisien. Peraturan pemerintah ini tentu dapat digunakan sebagai pedoman untuk meningkatkan efektivitas kinerja pegawai sekretariat DPRD di Kabupaten Ngawi. Hasil wawancara dengan Tri Pujo Handono menjelaskan bahwa :

"Implementasi Peraturan Pemerintah Nomor 18 Tahun 2016 yang ada pada Sekretariat DPRD Kabupaten Ngawi memang secara global mampu meningkatkan kinerja organisasi. Namun jika ditinjau dari masing-masing individu pegawai disini, tidak semuanya mampu bekerja lebih baik. Masih ada pegawai dengan kompetensi yang kurang sesuai kebutuhan organisasi yang harus kami terima dari pindahan staf dinas dan badan lain. Selain itu masih ada pegawai yang rendah disiplin kerjanya sehingga kurang dapat menunjukkan kinerja yang maksimal".

Hasil wawancara di atas menunjukkan bahwa tidak semua pegawai dapat bekerja secara optimal dalam mendukung pencapaian tujuan Sekretariat DPRD Kabupaten Ngawi. Implementasi Peraturan Pemerintah Nomor 18 Tahun 2016 tentang Perangkat Daerah di Kabupaten Ngawi membuat adanya penggabungan Dinas dan Badan sehingga terdapat pindahan pegawai yang kompetensinya tidak sesuai kebutuhan Sekretariat DPRD Kabupaten Ngawi. Hal ini membuat pegawai tidak mampu bekerja secara optimal sehingga kinerja pegawai juga cenderung rendah. Kompetensi sangat dibutuhkan dalam pelaksanaan tugas pegawai. Hasil Penelitian Subari and Riady menemukan bahwa "kompetensi berpengaruh langsung terhadap kinerja" (Subari and Riady, H., 2015: 142)

Penjelasan di atas juga menemukan adanya permasalahan disiplin kerja pegawai yang menghambat pencapaian kinerja pegawai sesuai dengan ketentuan organisasi. Tidak semua pegawai mampu menunjukkan disiplin kerja yang tinggi. Hukuman atau sanksi yang kurang tegas dan kurang mampu memberi efek jera membuat pegawai kurang disiplin dalam bekerja. Untuk itu budaya disiplin seperti yang diterapkan orang jepang perlu menjadi salah satu 
contoh bagi pegawai agar dapat bekerja dengan kedisiplinan kerja yang tinggi. Hasil penelitian Miller dan Toivonen menemukan bahwa "orang jepang memiliki kebiasaan disiplin kerja yang tinggi" (Aaron L. Miller and Tuukka Toivonen, 2010: 347). Apabila kebiasaan disiplin kerja seperti orang Jepang tersebut sudah dilakukan sejak awal berdirinya organisasi, tentu anggota organisasi yaitu para pegawai tentu akan dapat menunjukkan disiplin kerja yang tinggi sehingga mampu mencapai kinerja yang lebih baik lagi.

Berdasarkan penjelasan di atas dapat diketahui bahwa ditinjau dari unsur kultur hukum, maka implementasi Peraturan Pemerintah Nomor 18 Tahun 2016 tentang Perangkat Daerah di Kabupaten Ngawi kurang mampu meningkatkan efektivitas kinerja pegawai Sekretariat DPRD Kabupaten Ngawi. Kompetensi pegawai yang pindah dari adanya penggabungan Dinas dan Badan lain sesuai dengan Peraturan Pemerintah Nomor 18 Tahun 2016 tidak sesuai dengan kebutuhan Sekretariat DPRD Kabupaten Ngawi.

\section{Simpulan}

Berdasarkan hasil penelitian dan pembahasan yang telah dilakukan maka kesimpulan yang dapat diambil dalam penelitian ini antara lain adalah sebagai berikut :Kemampuan implementasi Peraturan Pemerintah Nomor 18 Tahun 2016 dalam meningkatkan efektivitas kinerja pegawai Sekretariat DPRD Kabupaten Ngawi, ditinjau dari struktur hukum adalah pemangku jabatan yang menjalankan peraturan pemerintah tersebut yaitu Sekretaris DPRD Kabupaten Ngawi, Kepala Bagian dan Kepala Sub Bagian yang ada pada Sekretariat DPRD Kabupaten Ngawi. Ditinjau dari substansi hukum, Implementasi Peraturan Pemerintah Nomor 18 Tahun 2016 tentang Perangkat Daerah mampu meningkatkan efektivitas kinerja pegawai Sekretariat DPRD Kabupaten Ngawi. Pemerintah Kabupaten Ngawi menetapkan Peraturan Bupati NgawiNomor 51 Tahun 2016 tentang Kedudukan, Susunan Organisasi, Tugas Dan Fungsi Serta Tata Kerja Sekretariat Dewan Perwakilan Rakyat Daerah Tipe Asebagai acuan pelaksanaan tugas pegawai. ditinjau dari unsur kultur hukum, maka implementasi Peraturan Pemerintah Nomor 18 Tahun 2016 tentang Perangkat Daerah di Kabupaten Ngawi kurang mampu meningkatkan efektivitas kinerja pegawai Sekretariat DPRD Kabupaten Ngawi. Kompetensi pegawai yang pindah dari adanya penggabungan Dinas dan Badan lain sesuai dengan Peraturan Pemerintah Nomor 18 Tahun 2016 tidak sesuai dengan kebutuhan Sekretariat DPRD Kabupaten Ngawi.

\section{E. Saran}

Saran yang bisa penulis berikan berdasarkan hasil penelitian yang dilakukan antara lain adalah sebagai berikut :

1. Efektivitas kinerja pegawai pada Sekretariat DPRD Kabupaten Ngawi perlu ditingkatkan dengan cara meningkatkan disiplin kerja pegawai. Untuk itu perlu dilakukan pemutakhiran data absensi pegawai menggunakan absensi sidik jari (finger print). Absensi ini juga dijadikan dasar untuk memberikan reward and punishment kepada pegawai sehingga pegawai dapat bekerja lebih baik. 
2. Kebijakan tentang pemberian penghargaan dan sanksi kepada pegawai perlu ditetapkan pada pada Sekretariat DPRD Kabupaten Ngawi mengacu pada peraturan perundangundangan yang berlaku. Hal ini akan membuat manajemen Sekretariat DPRD Kabupaten Ngawi mempunyai dasar hukum yang kuat dalam mengelola sumber daya manusia yang ada. Kepada Sekwan DPRD Kabupaten Ngawi dalam meningkatkan kinerja staf diharapkan lebih profesional dan mematuhi peraturan pemerintah yang telah berlaku.

\section{F. Daftar Pustaka}

\section{Buku}

Ahmad Kamarudin. 2008. Manajemen. Jakarta: Bumi Aksara.

Djoko Purwito. 2009. Metodologi Penelitian; Pendekatan Praktis Untuk Ilmu Ekonomi dan Ilmu Sosial. Ngawi: LPM-Unsoer.

Esmi Warassih. 2005. Pranata Hukum Sebuah Telaah Sosiologis. Semarang: Suryandaru Utama.

Heidjrachman Ranupandojo dan Suad Husnan. 2009. Manajemen Personalia. Yogyakarta: BPFE UGM.

Muhammad As'ad. 2007. Seri Ilmu Manajemen Sumber Daya Manusia. Psikologi Industri. Bandung: Alumni.

Richard M. Steers. 2005. Efektifitas Organisasi. Jakarta: Erlangga.

\section{Jurnal}

Aaron L. Miller and Tuukka Toivonen. 2010. "To Discipline or Accommodate? On the Rehabilitation of Japanese 'Problem Youth", The Asia-Pacific Journal: Japan Focus.

Richard W Warts. 1995."Toward the Simplification of Civil Service Disciplinary Procedures", Military Law ReviewJournal, Nbr. 150, October pp. 193.

Subari and Riady, H. 2015. "Influence of Training, Competence and Motivation on Employee Performance, Moderated By Internal Communications".American Journal of Business and Management, Vol. 4, No. 3.

\section{Internet}

Ali Habiu, Pandangan Tentang Peraturan Pemerintah Nomor 41 Tahun 2007 tentang Organisasi Perangkat Daerah. Ali-habiu.blogspot.com, diakses pada tanggal 16 Juli 2017.

Kurniawan. Restrukturisasi Birokrasi. kurnia-one75.blogspot.com. diakses 17 Juli 2017. 